\title{
Tergal gland components of reproductively dominant honey bee workers have both primer and releaser effects on subordinate workers
}

\author{
Olabimpe O. Okosun, Abdullahi A. Yusuf, Robin M. Crewe, Christian W. W. PiRK \\ Social Insects Research Group, Department of Zoology and Entomology, University of Pretoria, Private Bag X20, \\ Hatfield, Pretoria 0028, South Africa
}

Received 31 January 2018 - Revised 5 November 2018 - Accepted 14 December 2018

\begin{abstract}
The primer and releaser effects of dominant honey bee workers' tergal gland pheromones are not known under queenless conditions. The Cape honey bee, Apis mellifera capensis, is the ideal model to investigate such question since workers normally reproductively dominate workers of all other subspecies. We determined the effects that short- and long-term exposure to pheromone blends from dominant $A$. $m$. capensis workers had on subordinate workers of $A$. m. scutellata. Three putative pheromonal blends, 1 (palmitic acid, oleic acid, $n$-heneicosene and $n$ tricosene), 2 (ethyl palmitate, ethyl oleate and ethyl stearate) and 3 (mixture of blends $1+2$ ), were tested. All the three putative pheromonal blends elicited releaser effects in the form of retinue formation and primer effects by suppressing ovarian activation in workers. The resultant effects indicated that these pheromonal blends appear to play a role in establishing dominance among workers and hence regulating opportunities to reproduce.
\end{abstract}

\section{honey bee / tergal gland / queenless workers / social parasitism / primer and releaser pheromones}

\section{INTRODUCTION}

The pheromones produced by various glandular sources in honey bees are distinguishable by the effects that they have: the primer pheromones have long-term physiological effects, while releaser pheromones have short-term behavioural effects on receivers (Velthuis 1970; Le Conte and Hefetz 2008). These effects have been reported in a variety of social insects such as ants, termites, bumblebees and honey bees (Prestwich 1983; Vargo 1998; Pankiw 2004; Ayasse and Jarau 2014). In honey bees, the long-term primer effects of pheromones include delaying foraging age, delaying onset of swarming, suppression of ovarian activation and egg-laying in workers. The

Corresponding author: O. Okosun, bimpy@zoology.up.ac.za

Manuscript editor: Yves Le Conte releaser effects of these pheromonal signals include inhibition of emergency queen rearing in the colony, swarm stabilisation, calming of queenless workers, attraction of foragers to crops, attraction of drones to virgin queens and retinue formation around the queen (Pankiw 2004; Brockmann et al. 2006).

Honey bee queens' pheromones serve several purposes in the colony such as regulating reproductive capacity of receivers that are normally their daughters, with a strong evidence that the degree of dominance is dependent on the queen's age, the quality and dose of her pheromones received or perceived by workers (De Hazan et al. 1989; Smith et al. 1993; Hoover et al. 2005). Since reproductive dominance and control are achieved by pheromones, there exists strong evidence that pheromones from different glandular sources act in synergy depending on the context (Vierling and Renner 1977; De Hazan et al. 1989; Brockmann et al. 2006; Maisonnasse et al. 2010; 
Okosun et al. 2015, 2017). The tergal glands, located on tergites II-IV in queens and workers (Billen et al. 1986; Wossler et al. 2000), are important exocrine glands that produce long-chain fatty acids, long-chain esters and a series of unsaturated and saturated hydrocarbons as components (Smith et al. 1993; Wossler and Crewe 1999a; Okosun et al. 2015). The secretions from the tergal gland ensure queen dominance by eliciting both primer and releaser effects in workers (Renner and Vierling 1977; Vierling and Renner 1977; Wossler and Crewe 1999b, c).

In queenless situations, the production of queen glandular pheromones by workers allows them to take over the role of the queen and gain dominance (Sakagami 1958; Moritz et al. 2000; Schäfer et al. 2006; Zheng et al. 2010). These reproductively dominant workers also known as false queens develop glandular pheromones that are qualitatively similar to those of a queen, and the release of these pheromones prevents their nestmates from making a similar switch in the production of pheromonal components (Crewe and Velthuis 1980; Katzav-Gozansky et al. 2003; Härtel et al. 2011; Okosun et al. 2017). They escape the control systems in the colony by behaviourally avoiding the queen (Moritz et al. 2002) and lay eggs that are not policed (Malka et al. 2007). The false queens inhibit emergency queen rearing, suppress ovarian activation and elicit retinue behaviour from other workers just like a true queen (Sakagami 1958; Crewe and Velthuis 1980; Brockmann et al. 2006).

False queen phenomena are well exhibited by workers of the Cape honey bee Apis mellifera capensis, displaying characteristics that include rapidly activating their ovaries, developing queen-like mandibular, Dufour's and tergal gland pheromone bouquet in the case of queen loss (Hemmling et al. 1979; Ruttner and Hesse 1981; Moritz et al. 2000; Sole et al. 2002; Härtel et al. 2011; Okosun et al. 2017). They are successful social parasites in their own or in colonies of other honey bee races and can achieve pheromonal and reproductive dominance in other $A$. mellifera subspecies such as $A . m$. mellifera (Saiovici 1983), A. m. carnica (Hemmling et al. 1979) and A.m. scutellata (Schäfer et al. 2006; Okosun et al. 2017). The ability of $A . m$. capensis workers to achieve rapid pheromonal and reproductive dominance using secretions from mandibular and Dufour's gland is well established (Moritz et al. 2000; Sole et al. 2002; Zheng et al. 2010). However, how dominant workers use pheromones from the tergal glands to modify interactions with subordinate workers is still poorly understood.

Earlier on, potential tergal gland components of dominant honey bee workers that could be involved in controlling ovary activation in nest mates were identified (Okosun et al. 2015). These are palmitic acid, oleic acid, $n$-heneicosene and $n$-tricosene, $n$-pentacosene, $n$-heptacosene and $n$-nonacosene. Also included are three ethyl esters (ethyl palmitate, ethyl oleate and ethyl stearate) previously identified as part of the brood pheromones in European Apis mellifera (Le Conte et al. 1990), found in the larval salivary glands which have both primer and releaser effects on adult honey bee workers (Le Conte et al. 2001, 2006). Moreover, ethyl oleate was also found in foragers' heads and crops (Castillo et al. 2012) and acts as a source of primer pheromone by mediating worker-worker interaction (Leoncini et al. 2004a, b). These three ethyl esters were found in heads, thoraces and abdomens of European Apis mellifera queens' (Engels et al. 1997; Keeling et al. 2003; Keeling and Slessor 2005) of different reproductive status and had been suggested as potential queen "retinue pheromone" components (Keeling et al. 2003). These esters were ineffective alone and did not act addictively with the queen's mandibular pheromone (QMP) to elicit a retinue (Keeling et al. 2003). A follow-up study showed that none of the newly identified queen retinue pheromones' components inhibited ovarian activation in caged honey bee workers (Hoover et al. 2003).

These three esters (ethyl palmitate, ethyl oleate and ethyl stearate) have not been previously reported in tergal gland profiles of either queens or workers (Espelie et al. 1990; Smith et al. 1993; Wossler and Crewe 1999a) but were recently reported in tergal gland secretions of workers (Okosun et al. 2015). While, the exact functions of these tergal gland components as either primer or releaser pheromones are not known in workers, the queen's tergal gland extracts elicited attraction 
of drones and workers, as well as suppressed ovarian activation in workers (Vierling and Renner 1977; De Hazan et al. 1989; Brockmann et al. 2006; Wossler and Crewe 1999b, c).

Here, we investigated the effects of tergal gland pheromonal blends from dominant workers on subordinate workers. Firstly, by determining their releaser effects in a retinue behavioural bioassay, and secondly, the primer effects through assessing the inhibitory effects on ovarian activation of subordinate workers. Finally, the effects of the three ethyl esters from tergal glands of both $A . m$. capensis clones and A.m. scutellata workers (Okosun et al. 2015) were also determined.

\section{MATERIALS AND METHODS}

\subsection{Experimental setup}

A. $m$. scutellata brood frames from three different colonies were collected from the University of Pretoria experimental apiary. For the bioassay, an arena was made by drilling a small hole of about $1.5 \mathrm{~cm}$ on the top of a $9-\mathrm{cm}$ petri dish; this was covered with gauze so that the workers would have access to a $50 \%$ sugar-water mixture placed on this hole. In addition, a second hole $(0.5 \mathrm{~cm})$ was cut in the side of the petri dish through which small glass lures (pseudo-queens) containing the test chemical components were introduced (Kaminski et al. 1990; Wossler and Crewe 1999b). The glass lures were made out of glass Pasteur pipettes by first heating in a flame at one end to seal them and then making a depression on the surface by applying gentle suction from the open end. The indentation was large enough to hold $10 \mu \mathrm{l}$ of the test material. Once the indentation was made, the open end was heated and sealed off.

\subsection{Pseudo-queen tergal gland blend}

Compounds termed potential tergal gland pheromonal components from $A$. $m$. capensis clones and $A$. $m$. scutellata workers (palmitic acid, oleic acid, $n$-heneicosene and $n$-tricosene) and the three ethyl esters (ethyl palmitate, ethyl oleate and ethyl stearate) (Okosun et al. 2015) were tested in this study. The average concentration of tergal glands secretions of one dominant $A . m$. capensis worker clone equivalent (Weq) was calculated from Okosun et al. (2015) and then scaled to 10 Weq. Based on the average amounts reported by Okosun et al. (2015), the amounts of each of these seven compounds (palmitic acid $(0.314 \mathrm{mg})$, oleic acid $(0.348 \mathrm{mg}), n$-heneicosene $(0.134 \mathrm{mg})$, $n$-tricosene $(0.125 \mathrm{mg})$, ethyl palmitate $(0.068 \mathrm{mg})$, ethyl oleate $(0.087 \mathrm{mg})$ and ethyl stearate $(0.19 \mathrm{mg})$ ) were dissolved in $5 \mathrm{ml}$ of $n$ hexane. Thereafter, $5 \mu$ of the solution equivalent of 10 Weq was used in each of the bioassays. Three pheromonal blends of the tergal gland at 10 Weq were used: blend 1 (palmitic acid, oleic acid, $n$-heneicosene and $n$-tricosene), blend 2 consisting of the three identified ethyl esters (ethyl palmitate, ethyl oleate and ethyl stearate) and blend 3, a mixture of blends $1+2$. All synthetic standards (palmitic acid P0500-10G, oleic acid 01008-1G, $n$-heneicosene 249238-5G, $n$ tricosene 859885-1G, ethyl palmitate P9009-5G, ethyl oleate O-9500-5G and ethyl stearate S8269$5 \mathrm{G}$ ) and the solvent ( $n$-hexane 34,859-2.5 1) were purchased from Sigma Aldrich (St. Louis, MO, USA).

\subsection{Retinue attraction bioassay (releaser effect)}

A behavioural bioassay of workers to tergal gland components was carried out using a laboratory bioassay with 9-cm inner diameter petri dishes following the protocol of Kaminski et al. (1990) and Wossler and Crewe (1999b). Different pheromonal blends were placed on pseudo-queen lures with a microsyringe, and the solvent (hexane) was allowed to evaporate. Thereafter, lures were introduced through the hole at the side of the petri dish into the bioassay arena. Hexane was used as a control, which was also allowed to evaporate before the start of the bioassay. For each bioassay treatment, 15 young honey bee workers of 0-3 days old were randomly collected from each of the three different experimental colonies and introduced into the bioassay arena. To avoid bias, between treatments, fresh new bees were used for each treatment on bioassay days. Preliminary observation showed that tested bees take time to respond to an introduced lure; a 20-min 
observation period instead of $15 \mathrm{~min}$ (Wossler and Crewe 1999b) was then used to allow workers enough time to respond to the pseudo-queen lure. The response of workers to the introduced lure was videotaped under red light for $20 \mathrm{~min}$ in a controlled temperature room $\left(27^{\circ} \mathrm{C}\right)$. Retinue behaviour was analysed by replaying the videotape, which was paused every $30 \mathrm{~s}$, and the number of workers contacting lure and within active retinue ellipse of one worker length $(1.2 \mathrm{~cm})$ was counted while each 30 -s interval was treated separately. The three experimental colonies were assayed four times with 12 replicates for each treatment. Replicates consisted of fresh treatment blends to new naïve bees on subsequent bioassay days (Kaminski et al. 1990; Wossler and Crewe 1999b; Keeling et al. 2003; Hoover et al. 2005). In all, 480 observations per treatment blend were made across the three different colonies; each observation consists of 30 -s periods within the 20-min observation period (i.e., 40 observations for each $20 \mathrm{~min}$ assay).

\subsection{Suppression of ovarian activation (primer effect)}

Honey bee workers used for this experiment were obtained from three experimental colonies that were different from the ones used for the retinue attraction assays. Thirty newly emerged A.m. scutellata workers were housed in standard cages (Köhler et al. 2013) and provided with sugar solution, water and pollen ad libitum (Wossler and Crewe 1999c; Hoover et al. 2005).

Ten worker equivalents were placed on a glass slide (the lure from here onwards) and introduced into the cage; workers in the control cages were exposed to the lure that has only solvent placed on it. The solvent $(10 \mu \mathrm{l}$ of hexane) was allowed to evaporate before introducing the lure into the cage. Thereafter, the cages were incubated at optimum temperature and relative humidity (Pirk et al. 2010). Since workers of both $A . m$. scutellata and $A . m$. capensis have a latency period (period to activating ovaries after queen loss) which is shorter than 10 days (Ruttner and Hesse 1981), monitoring was done for 10 days and lures were replaced with new ones daily. For each trial, 30 newly emerged workers from the three source colonies were placed in separate cages per each treatment blend $(N=4)$, making 12 experimental cages ( 3 cages $\times 4$ treatments) comprising of 360 bees. To maintain a cohort of honey bees, any worker that died in the first 2 days of the experiment trial was replaced with a 1-day old honey bee worker. All remaining bees at the end of the trial were frozen, their ovaries dissected and the stage of ovariole activation ranked as stages 1, 2, 3, 4, and 5 (Hess 1942; Pirk et al. 2010). Since $A . m$. scutellata workers need at least 7 days under cage conditions to activate their ovaries (Okosun et al. 2015), bees dying from the 7th day onwards were frozen; their ovarian activation was recorded and included in the final analysis.

\subsection{Statistical analyses}

For retinue bioassays, the releaser effects of tergal gland pheromone on host workers were determined using the Kruskal-Wallis test followed by a post hoc test (multiple comparisons of mean ranks) since data were not normally distributed (Shapiro Wilks test) (Pirk et al. 2013). Treatment blends were the grouping variable and number of contacts per $30 \mathrm{~s}$ as the dependent variable. Also, Kruskal-Wallis test followed by a post hoc test (multiple comparisons of mean ranks) was used to determine the primer effects. Ovary scores of bees exposed to different blends were analysed using treatment blends as grouping variable and ovary scores of individual workers as the dependent variable. To determine the effect of pheromonal blend on the survival of bees exposed to different blends, Kaplan-Meier survival regression analyses were performed with treatment blend as grouping variables. Significance levels were set at $a<0.05$, and all analyses were performed using Statistica 12 (StatSoft USA).

\section{RESULTS}

\subsection{Retinue attraction bioassay (releaser effect)}

In the retinue bioassay, there were significant differences in the responses of workers to the different treatment blends and the control (KWA: 


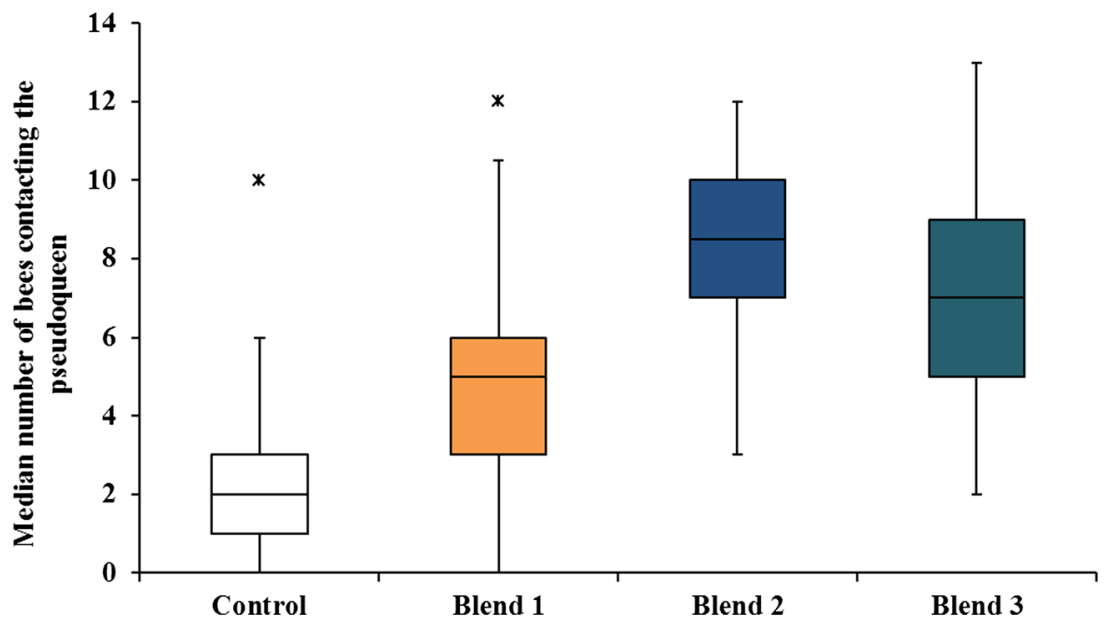

Figure 1 Retinue attraction of $A . m$. scutellata workers to the different tergal gland blends in the pseudo-queen bioassay. Blend 1 (palmitic acid, oleic acid, $n$-heneicosene and $n$-tricosene); blend 2 (ethyl palmitate, ethyl oleate and ethyl stearate); blend 3 (mixture of blends $1+2$ ); control (hexane). The median line, quartile, whisker and outliers are shown. Number of observation per treatment blend $(N=480)$.

$\mathrm{H}(3, N=1920)=667.362 ; P<0.05)($ Figure 1$)$. Among the different blends, blend 1 was less attractive to A. m. scutellata workers and was significantly different from blends $2(Z=4.409$; $P<0.05)$ and $3(Z=3.416 ; P<0.05)$, while blends 2 and 3 attracted more bees and were not significantly different from each other $(Z=0.993$; $P>0.05)$.

\subsection{Suppression of ovarian activation (primer effect)}

The ovarian activation scores in $A . m$. scutellata workers were significantly affected by the treatment (KWA: H $(3, N=158)=17.60$; $P<0.001)$ (Figure 2). The three blends were significantly different from the control: blend $1(Z=$ 3.242; $P<0.05)$, blend $2(Z=3.203 ; P<0.05)$ and blend $3(Z=2.974 ; P<0.05)$ (Figure 2$)$. Ovarian activation score Mdn (IQR) of bees exposed to blend $1(N=43)$ was 1 (IQR $=1-2)$, blend $2(N=50)$ was $1(\mathrm{IQR}=1-2)$ and blend 3 $(N=39)$ was 1 (IQR $=1-2)$, while control $(N=$ 26) was $2(\mathrm{IQR}=1-3)$ Figure 2.

Survival of bees in hoarding cages while being exposed to different tergal gland pheromonal blends was not affected as shown in Figure 3. Mean survival $( \pm \mathrm{SD}$ ) for blend 1 was $6.78 \pm$
2.53 days, blend 2 was $7.34 \pm 2.31$ days, blend 3 was $6.64 \pm 2.57$ days and control was $5.70 \pm$ 2.54 days.

\section{DISCUSSION}

The workers' tergal gland secretions that included the three ethyl esters found in Apis mellifera workers (Okosun et al. 2015) have both primer and releaser effects as shown in these results. Tergal gland fatty acids and unsaturated hydrocarbon (blend 1) were the least attractive out of the three blends. Blend 2 (ethyl esters alone) had enhanced attractiveness, while the blend of the two mixtures was not significantly different from that of blend 2 on its own. This inclusion of the ethyl esters in the bioassays confirms the overall attractiveness of this tergal gland blends and confirms the tergal gland's involvement in reproductive regulation either when emitted by the queen (De Hazan et al. 1989; Smith et al. 1993; Wossler and Crewe 1999c) or by workers as shown here. The tergal gland pheromones' releaser effects shown here compliment reports that queen-like secretions of the mandibular (Sakagami 1958; Crewe and Velthuis 1980; Moritz et al. 2000) and Dufour's gland (Sole et al. 2002; Katzav-Gozansky et al. 2003) of 


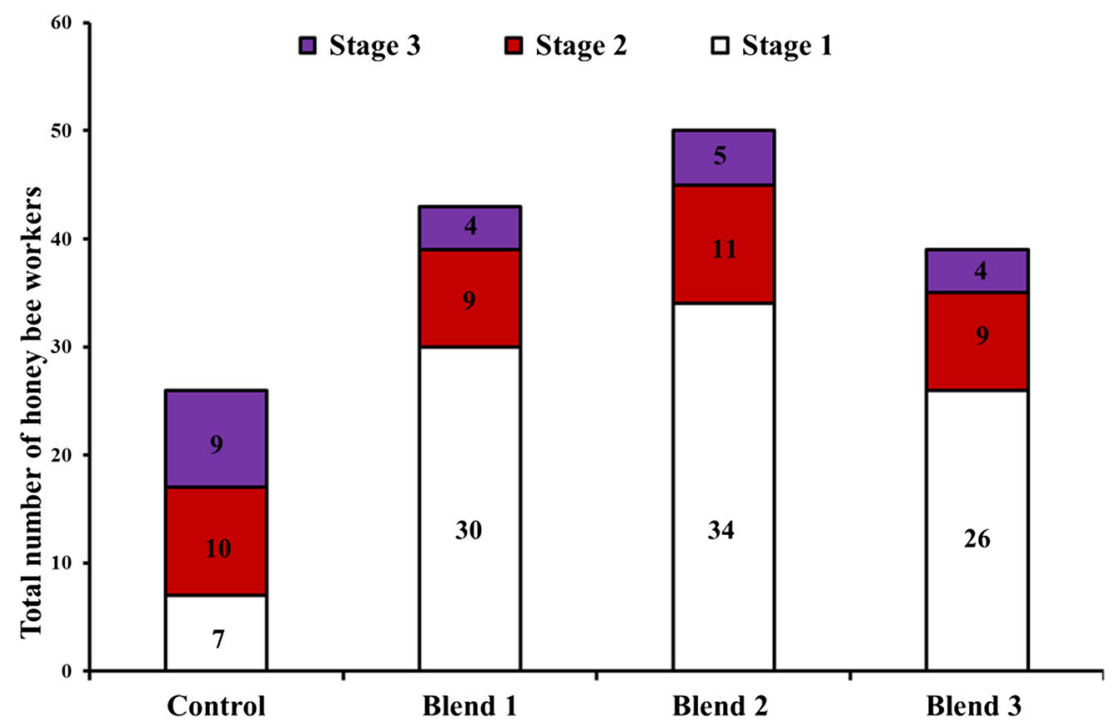

Figure 2 Number of bees with different stages of ovarian activation in A.m. scutellata workers exposed to different blends. Blend 1 (palmitic acid, oleic acid, $n$-heneicosene and $n$-tricosene); blend 2 (ethyl palmitate, ethyl oleate and ethyl stearate); blend 3 (mixture of blends $1+2$ ); control (hexane). $N$ is the number of bees dissected at different ovarian stages per treatment blend.

reproductively dominant workers are attractive to secretion have also been reported in other social nestmates. Similar releaser effects of tergal gland insects, such as in the bumble bee, Bombus

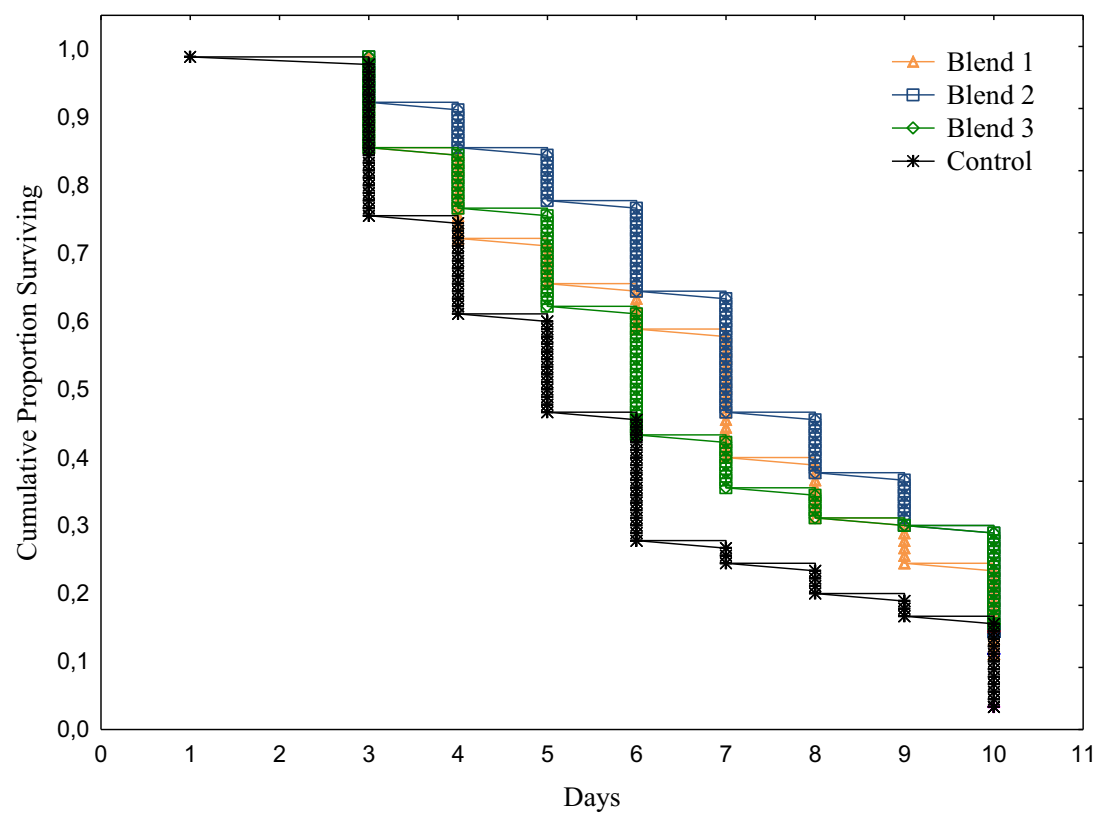

Figure 3 Survival of A . m . scutellata workers bees exposed to different tergal gland pheromonal blends. Blend 1: palmitic acid, oleic acid, $n$-heneicosene and $n$-tricosene; blend 2: ethyl palmitate, ethyl oleate and ethyl stearate; blend 3: mixture of blends $1+2$; control: hexane. $*$ Orange open triangle and solid lines $=$ blend 1 ; blue open squares and solid lines $=$ blend 2; green open diamonds and solid lines $=$ blend 3 and black stars and solid lines $=$ control. 
terrestris (Dornhaus et al. 2003) and termites, Coptotermes formosanus (Raina et al. 2005) and Cornitermes bequaerti (Bordereau et al. 2002).

The potential "retinue pheromones" components from European honey bees tested by Keeling et al. (2003) did not have any effects on their own without the addition of queen mandibular pheromones (QMPs). However, we show here that three of these previously suggested retinue pheromones' components in blends 2 and 3 actually elicit retinue behaviour on their own without QMPs in African honey bees. This supports the role of the tergal gland being a source of a retinue pheromone blend produced by reproductively dominant workers that is attractive to other nestmates and elicits attraction of subordinate workers. Indeed, our results confirm earlier suggestions that queen-like glandular secretions of reproductively dominant workers from the abdomen (Saiovici 1983), mandibular gland (Moritz et al. 2000; Malka et al. 2008) and from the Dufour's gland (Sole et al. 2002; KatzavGozansky et al. 2003; Malka et al. 2008) allow for the establishment of reproductive dominance.

The primer effects of these ethyl esters when present in larval brood pheromone and foragers crops include regulation of food supply for the colony, delayed transitioning from nurse bees to foragers or accelerated development of nurse bees to foragers thereby regulating foraging to maintain colony cohesion and organisation (Leoncini et al. 2004b; Le Conte et al. 2006; Castillo et al. 2012). This strategy of regulating foraging could be used by socially parasitic $A$. $m$. capensis workers and allows host workers to tend to their needs because dominant honey bee workers do not participate in colony duties (Hillesheim et al. 1989). They rather mimic and release glandular queen-like signals (Moritz et al. 2000; Sole et al. 2002; Okosun et al. 2017) that elicit retinue behaviour and attract workers to feed them high-quality food such as royal jelly through trophallaxis (Korst and Velthuis 1982; Moritz and Crailsheim 1987; Schäfer et al. 2006) and further establish dominance. Ethyl oleate in honey bee colonies delayed onset of foraging and transitioning of nurse bees to foragers (Leoncini et al. 2004b; Castillo et al. 2012). The presence of these esters in reproductively dominant workers could be used to ensure the survival of subordinates while at the same time inhibiting ovarian activation in subordinates towards maintaining reproductive dominance hierarchy within the colony. Despite the short life span of the workers under these experimental conditions, they lived sufficiently long to be able to demonstrate the primer effects of the pheromone blends that were tested. Although we do not know the reason for the short life span, it was most likely an unknown environmental factor which however affected all groups in the same way.

Suppression of ovarian activation in the experimental workers in this study was a result of exposure to tergal gland pheromonal blends equivalence of dominant workers because other contributing factors to the inhibition of ovarian activation such as presence or absence of queen and brood pheromone (Velthuis 1970; Mohammedi et al. 1998; Malka et al. 2007) were absent. Mohammedi et al. (1998) showed under queenless and broodless conditions that ethyl palmitate was indeed involved in supressing ovarian development in caged bees. Moreover, dominant A.m. capensis workers without their mandibular glands were able to prevent ovarian activation in other sister subspecies, A.m. mellifera (Saiovici 1983), further supporting the role of a number of glands such as the tergal gland in reproductive division of labour (Okosun et al. 2017).

The tergal gland components including the three ethyl esters acted as both primer and releaser pheromones and contributed to establishing dominance within groups of experimental workers. This provides an insight into how pheromonally dominant workers can achieve reproductive dominance using secretions from a diversity of glandular sources. This result offers the prospects of using synthetic tergal gland pheromone blends in the management of reproduction in workers and especially in management of parasitic infestation in apiaries.

\section{ACKNOWLEDGMENTS}

We thank Mr. Tlhogi Selaledi for his technical assistance. 


\section{AUTHORS' CONTRIBUTIONS}

OOO, AAY, RMC and CWWP conceptualised and designed experiments; OOO performed experiments; all authors contributed and edited the manuscript.Funding information

This work is supported in part by the National Research Foundation (NRF) of South Africa's Competitive Programme for rated researchers and incentive funding to CWWP, RMC and AAY (grant numbers 90579, 111683, 103710 and 109380), NRF Research Career Advancement Fellowship (grant number 91419) to AAY, NRF Scarce Skills Postdoctoral Fellowship to OOO (Grant number 108019) and University of Pretoria, South Africa.

\section{COMPLIANCE WITH ETHICAL STANDARDS}

Conflict of interest The authors declare that they have no conflict of interest.

Les composants des glandes tergales d'ouvrières à dominante reproductrice ont à la fois des fonctions de phéromones modificatrices et de pheromones de déclenchement

Abeille domestique / glande tergale / ouvrières sans reine / parasitisme social / phéromones modificatrices et de déclenchement

Komponenten der Tergitdrüsen von reproduktiv dominanten Arbeiterinnen haben sowohl Primer- als auch Releaserpheromonfunktionen

Honigbiene / Tergitdrüsen / weisellose Arbeiterinnen / Sozialparasitismus / Primer- und Releaserpheromone

Publisher's note Springer Nature remains neutral with regard to jurisdictional claims in published maps and institutional affiliations.

\section{REFERENCES}

Ayasse, M., Jarau, S. (2014) Chemical ecology of bumble bees Annu. Rev. Entomol. 59, 299-319
Billen, J. P. J., Dumortier, K. T. M., Velthuis, H.H.W. (1986) Plasticity of honey bee castes. Naturwissenschaften 73, 332-333

Bordereau, C., Cancello E.M., Sémon, E., Courrent, A., Quennedey, B. (2002) Sex pheromone identified after solid phase microextraction from tergal glands of female alates in Cornitermes bequaerti (Isoptera, Nasutitermitinae). Insect. Soc. 49, 209-215

Brockmann, A., Dietz, D., Spaethe, J., Tautz, J. (2006) Beyond 9-ODA: sex pheromone communication in the European honey bee Apis mellifera L. J. Chem. Ecol. 32, 657-667

Castillo, C., Chen, H., Graves, C., Maisonnasse, A., Le Conte, Y., Plettner, E. (2012) Biosynthesis of ethyl oleate, a primer pheromone, in the honeybee (Apis mellifera L.). Insect Biochem. Mol. Biol. 42, 404- 416

Crewe, R.M., Velthuis, H. H. W. (1980) False queens: a consequence of mandibular gland signals in worker honeybees. Naturwissenschaften 67, 467-469

De Hazan, M., Lensky, Y., Cassier, P. (1989) Effects of queen honeybee (Apis mellifera L.) ageing on her attractiveness to workers. Comp. Biochem. Physiol. A Physiol. 93, 777-783

Dornhaus, A., Brockmann, A. E., Chittka, J. (2003) Bumble bees alert to food with pheromone from tergal gland. J. Comp. Physiol. A. 189, 47-51

Engels, W., Rosenkranz, P., Adler, A., Taghizadeh, T., Lübke, G., Francke, W. (1997) Mandibular gland volatiles and their ontogenetic patterns in queen honey bees, Apis mellifera carnica. J. Insect Physiol. 43, 307-313

Espelie, K.E., Butz, V.M., Dietz, A. (1990) Decyl decanoate: a major component of the tergite glands of honey bee queens (Apis mellifera L). J. Apic. Res. 29, 15-19

Härtel, S., Wossler, T. C., Moltzer, G. J., Crewe, R. M., Moritz, R. F. A., Neumann, P. (2011) Pheromone mediated reproductive dominance hierarchies among pseudo-clonal honeybee workers (Apis mellifera capensis Esch.). Apidologie 42, 659-668

Hemmling, C., Koeniger, N., Ruttner F. (1979) Quantitative bestimmung der 9-oxodecensäure im lebenszyklus der kapbiene (Apis mellifera capensis escholtz). Apidologie 10, 227-240

Hess, G. (1942) Uber die Einfluss der Weisellosigheit und des Fruchtbarkeits-vitamins E auf die Ovarien der Bienearbeiterin. Beihefte. der Schwz. Bienen. Zeitung 1, 33-109

Hillesheim, E., Koeniger, N., Moritz, R. F. A. (1989) Colony performance in honey bees (Apis mellifera capensis Esch.) depends on the proportion of subordinate and dominant workers. Behav. Ecol. Sociobiol. 24, 291-296

Hoover, S.E.R., Keeling, C.I., Winston, M.L., Slessor, K.N. (2003) The effect of queen pheromones on worker honey bee ovary development Naturwissenschaften 90, 477-480

Hoover, S. E, Winston, M. L, Oldroyd, B. P. (2005) Retinue attraction and ovary activation: responses of wild type 
and anarchistic honey bees (Apis mellifera) to queen and brood pheromones. Behav. Ecol. Sociobiol. 59, 278-284

Kaminski, L-A., Slessor, K. N., Winston, M. L., Hay, N. W., Borden, J. H. (1990) Honeybee response to queen mandibular pheromone in laboratory bioassays. J. Chem. Ecol. 16, 841-850

Katzav-Gozansky, T., Soroker, V., Francke, W., Hefetz, A. (2003) Honeybee egg-laying workers mimic a queen signal. Insect. Soc. 50, 20-23

Keeling, C. I., Slessor, K. N. (2005). A scientific note on the aliphatic esters in queen honey bees. Apidologie 36, 559-560

Keeling, C. I., Slessor, K.N., Higo, H.A., Winston, M.L. (2003) New components of the honey bee (Apis mellifera L.) queen retinue pheromone. Proc. Natl. Acad. Sci. 100, 4486-4491

Köhler, A., Nicolson, S. W., Pirk, C. W. W. (2013) A new design for honey bee hoarding cages for laboratory experiments. J. Apic. Res. 52, 12-14

Korst, P. J. A. M., Velthuis, H. H. W. (1982) The nature of trophallaxis in honeybees. Insect. Soc. 29, 209-221

Le Conte, Y., Hefetz, A. (2008) Primer pheromones in social hymenoptera. Annu. Rev. Entomol. 53, 523542

Le Conte, Y., Arnold, G., Trouiller, J., Masson, C. (1990) Identification of a brood pheromone in honey bees. Naturwissenschaften 77, 334-336

Le Conte Y., Mohammedi, A., Robinson, G.E. (2001) Primer effects of a brood pheromone on honey bee behavioural development. Proc. R. Soc. Lond. B Biol. Sci. 268, 163-168

Le Conte Y., Bécard J-M., Costagliola, G., de Vaublanc, G., El Maâtaoui, M., Crauser, D., Plettner, E., Slessor, K.N. (2006) Larval salivary glands are a source of primer and releaser pheromone in honey bee (Apis mellifera L.). Naturwissenschaften 93, 237-241

Leoncini, I., Crauser, D., Robinson, G. E., Le Conte, Y. (2004a). Worker-worker inhibition of honey bee behavioural development independent of queen and brood. Insect. Soc. 51 , 392-394

Leoncini, I., Le Conte, Y., Costagliola, G., Plettner, E., Toth, A. L, Wang, M., Huang, Z., Bécard, JM., Crauser, D., Slessor, K. N. (2004b) Regulation of behavioral maturation by a primer pheromone produced by adult worker honey bees. Proc. Nat. Acad. Sci. U. S. A. 101, 1755917564

Maisonnasse, A., Alaux, C., Beslay, D., Crauser, D., Gines, C., Plettner, E., Le Conte, Y. (2010) New insights into honey bee (Apis mellifera) pheromone communication. Is the queen mandibular pheromone alone in colony regulation? Front. Zool. 7, 18

Malka, O., Shnieor, S., Hefetz, A., Katzav-Gozansky, T. (2007) Reversible royalty in worker honeybees (Apis mellifera) under the queen influence. Behav. Ecol. Sociobiol. 61, 465-473
Malka, O., Shnieor, S., Katzav-Gozansky, T., Hefetz, A. (2008) Aggressive reproductive competition among hopelessly queenless honey bee workers triggered by pheromone signaling. Naturwissenschaften 95, 553559

Mohammedi, A., Paris, A., Crauser, D., Le Conte, Y. (1998) Effect of aliphatic esters on ovary development of queenless bees (Apis mellifera L.). Naturwissenschaften 85, 455-458.

Moritz, B., Crailsheim, K. (1987) Physiology of protein digestion in the midgut of the honeybee (Apis mellifera L.). J. Insect Physiol. 33, 923931

Moritz, R. F. A., Simon, U. E., Crewe, R. M. (2000) Pheromonal contest between honeybee workers (Apis mellifera capensis ). Naturwissenschaften 87, 395397

Moritz, R. F. A., Crewe, R. M., Hepburn, H. R. (2002) Queen avoidance and mandibular gland secretion of honeybee workers (Apis mellifera L.). Insect. Soc. 49, 86-91

Okosun, O. O., Yusuf, A. A., Crewe, R. M., Pirk, C. W. W. (2015). Effects of age and reproductive status on tergal gland secretions in queenless honey bee workers, Apis mellifera scutellata and A. m. capensis. J. Chem. Ecol. 41, 896-903

Okosun, O. O., Pirk, C. W. W., Crewe, R. M., Yusuf, A. A. (2017). Glandular sources of pheromones used to control host workers (Apis mellifera scutellata) by socially parasitic workers of Apis mellifera capensis. J. Insect Physiol. 102, 42-49

Pankiw, T. (2004) Cued in: honey bee pheromones as information flow and collective decision-making. Apidologie 35, 217-226

Pirk, C. W. W., Boodhoo, C., Human, H., Nicolson, S.W. (2010) The importance of protein type and protein to carbohydrate ratio for survival and ovarian activation of caged honeybees (Apis mellifera scutellata) Apidologie 41, 62-72

Pirk, C. W. W., de Miranda, J. R., Kramer, M., Murray, T. E., Nazzi, F., Shutler, D., van der Steen, J. J. M., van Dooremalen, C. (2013) Statistical guidelines for Apis mellifera research. J. Apic. Res. 52, https://doi. org/10.3896/IBRA.1.52.4.13

Prestwich, G. D. (1983) Chemical systematics of termite exocrine secretions. Annu. Rev. Ecol. Syst. 14, 287311

Raina, A. K., Park, Y. I., Ingber, B. F., Murphy, C. (2005) Structure and developmental changes in the tergal glands of adult females of Coptotermes formosanus (Isoptera, Rhinotermitidae). Arthropod Struct. Dev. 34, 117-124

Renner, M., Vierling, G. (1977) Die rolle des taschendrüsenpheromons beim hochzeitsflug der bienenkönigin. Behav. Ecol. Sociobiol. 2, 329-338

Ruttner, F., Hesse, B. (1981) Rassenspezifische Unterschiede In Ovarentwicklung Und Eiablage Von Weisellosen Arbeiterinnen Der Honigbiene Apis mellifera L. Apidologie 12:159-183 
Saiovici, M. (1983) 9-Oxodecenoic acid and dominance in honeybees. J. Apic. Res. 22, 27-32

Sakagami, S. F. (1958) The false-queen: fourth adjustive response in dequeened honeybee colonies1. Behaviour 13, 280-295

Schäfer, M. O., Dietemann, V., Pirk, C. W. W., Neumann, P., Crewe, R. M., Hepburn, H. R., Tautz, J., Crailsheim, K. (2006) Individual versus social pathway to honeybee worker reproduction (Apis mellifera): pollen or jelly as protein source for oogenesis? J. Comp. Physiol. A. 192, 761-768

Smith, R-K., Spivak, M., Taylor Jr, O. R., Bennett, C., Smith, M. L. (1993) Maturation of tergal gland alkene profiles in European honey bee queens, Apis mellifera L. J. Chem. Ecol. 19, 133-142

Sole, C. L., Kryger, P., Hefetz, A., Katzav-Gozansky, T., Crewe, R. M. (2002) Mimicry of queen Dufour's gland secretions by workers of Apis mellifera scutellata and A. m. capensis . Naturwissenschaften 89, 561-564

Vargo, E. (1998) Primer pheromones in ants. In Vander Meer, R.K., Breed, M. D., Espelie, K. E. and Winston, M. L. (Eds), Pheromone communication in social insects- ants, wasps, bees, and termites. Westview, Boulder, pp 293-313
Velthuis, H. H. W. (1970) Ovarian development in Apis mellifera worker bees. Entomol. Exp. Appl. 13 , 377-394

Vierling, G., Renner, M. (1977) Die Bedeutung des Sekretes der Tergittaschendrüsen für die Attraktivität der Bienenkönigin gegenüber jungen Arbeiterinnen. Behav. Ecol. Sociobiol. 2, 185-200

Wossler, T. C., Crewe, R. M. (1999a) Mass spectral identification of the tergal gland secretions of female castes of two African honey bee races (Apis mellifera). J. Apic. Res. 38, 137-148

Wossler, T. C., Crewe, R. M. (1999b) The releaser effects of the tergal gland secretion of queen honeybees (Apis mellifera ). J. Insect Behav. 12, 343-351

Wossler, T. C., Crewe, R. M. (1999c) Honeybee queen tergal gland secretion affects ovarian development in caged workers. Apidologie 30, 311-320

Wossler, T. C., Veale, R. B., Crewe, R. M. (2000) How queen-like are the tergal glands in workers of Apis mellifera capensis and Apis mellifera scutellata? Apidologie 31, 55-66

Zheng, H-Q., Dietemann, V., Crewe R. M., Hepburn, R., Hu, FL., Yang, M-X., Pirk, C. W. W. (2010) Pheromonal predisposition to social parasitism in the honey bee Apis mellifera capensis . Behav. Ecol. 21, 1221-1226 